Marquette University

e-Publications@Marquette

3-1-2009

Manufacturing FDI and Economic Growth: Evidence from Asian Economies

Miao Wang

Marquette University, grace.wang@marquette.edu

Accepted version. Applied Economics, Vol. 41, No. 8 (March 2009): 991-1002. DOI. (C) 2009 Taylor \& Francis (Routledge). Used with permission. 


\section{Manufacturing FDI and Economic Growth: Evidence from Asian Economies}

By Miao Wang

Previous empirical studies on inward foreign direct investment (FDI) and economic growth generate mixed results. This article suggests that the ambiguous results might be caused by the use of total FDI. We study the heterogeneous effects of different sector-level FDI inflows on host country's economic growth. Data from 12 Asian economies over the period of 1987 to 1997 are employed. Strong evidence shows that FDI in manufacturing sector has a significant and positive effect on economic growth in the host economies. FDI inflows in nonmanufacturing sectors do not play a significant role in enhancing economic growth. Furthermore, without the decomposition of total FDI inflows, the effect of manufacturing FDI on host country's economic growth is understated by at least $48 \%$.

\section{Introduction}

Foreign direct investment (FDI) is considered a vehicle transferring both tangible assets and intangible assets such as advanced technology, better managerial skill and innovative product designs. Theoretically speaking, capital formation and technological improvement are the engines of economic growth. As a result, FDI is expected to promote host countries' economic growth. It is generally accepted that the positive impact of FDI on growth is driven by FDI transferring assets relating to productivity improvement, or the spillover effect of FDI. However, the empirical evidence concerning FDI and economic growth is mixed. A number of articles that explore economic growth have argued that FDI promotes host countries' economic growth directly or under certain circumstances. Among these articles are Blomstrom et al. (1994), Borensztein et al. (1998) and Liu et al. (2002) (see also Alfaro et al., 2004; Blonigen and Wang, 2005; Kottaridi, 2005; Yao, 2006). For example, based on data from China over the period of 1978 to 2000, Yao (2006) finds that FDI has a significantly positive effect on economic growth. Borensztein et al. (1998) find that FDI can only contribute to economic growth when the host country reaches a certain level of human capital. However, others find little or no evidence of FDI promoting host countries' economic growth. Chakraborty and Basu (2002) argue that based on a time-series study, FDI does not Granger cause GDP in India. It is actually faster economic growth that attracts increased volume of FDI inflows (see also Choe, 2003; Choi, 2004; Carkovic and Levine, 2005).

\section{Wang 1}


With regard to the reasons for the ambiguous results, it can be caused by potential errors in the estimation method (Nair-Reichert and Weinhold, 2001). Mencinger (2003) finds a negative growth effect of FDI in eight transitional economies over the period of 1994 to 2001. The author proposes several reasons for a negative growth effect of FDI such as the form of FDI, including majority as Mergers and Acquisitions (M\&A) in these eight economies and the proceeds of $M \& A$ are spent on imports. This causes an increase in the current account deficit. De Mello (1997) points out that the actual growth effect depends on several channels through, which FDI can affect the host economies such as knowledge spillovers and complementarity or substitutability between FDI and host country domestic investment. Similar arguments are shared by the United Nations Economic Commission for Europe (UNECE). The Economic Survey for Europe (UNECE, 2001) states that the growth effect of FDI in transitional recipient economies depends on actual circumstances in those host countries.

In our article, we suggest that one possible reason for the mixed evidence in the empirical FDI-Growth literature is the use of total FDI. Multinational Corporations (MNCs) undertake FDI in different sectors in the host country, such as agricultural, manufacturing, or financial sectors. When using total FDI, previous studies have been making a strong assumption that FDI in different sectors has the same impact on host country's economic growth. If different sector-level FDI contributes differently to economic growth, the aggregation can blur the actual growth effect and lead to ambiguous results.

To our knowledge, there is no systematic empirical study on the growth effects of inward FDI in different sectors in the literature. Inward FDI in various sectors are different in nature and volume. For instance, spillover effect of FDI is considered more likely to occur in manufacturing sector than in other sectors and the empirical discussions of spillover effect are often based on FDI in manufacturing industries/sector (Chuang and Lin, 1999; Chuang and Hsu, 2004). It raises interesting questions: does FDI in manufacturing sector have the same impact on growth as FDI in agricultural sector? Or is there important heterogeneity across sectors in the effect of FDI on growth?

In this article, we undertake the analysis based on a unique data set that consists of both total and disaggregated FDI data for 12 Asian economies over the period of 1987 to 1997 . Our article contributes to the existing literature in three respects.

First, with our unique data for Asian economies, we focus on sector-level FDI instead of total FDI inflows in this study. Our results show that FDI in different sectors does have different impacts on host country's economic growth. Aggregating different types of FDI together could blur the actual growth effect of FDI and generate mixed results.

\section{Wang 2}


Second, we further find that previous studies underestimate the growth effect of manufacturing FDI because of aggregation. Our results indicate that the growth effect of manufacturing FDI is much stronger than the growth effect of total FDI. It appears that when different types of inward FDI are aggregated, the actual effect of manufacturing FDI on host country's economic growth could be understated by $48 \%$.

Third, our study provides better policy guidance to developing countries (LDCs). FDI inflows in LDCs have grown dramatically from $\$ 10$ billion in 1986 to $\$ 163$ billion in 1997. In addition to the increasing volume, FDI is playing an important role in private capital flows to LDCs. For example, FDI inflows represented $66.8 \%$ of total private capital flows to LDCs in 1998 , compared with a 38.5\% in 1990 (Perkins et al., 2001). Furthermore, manufacturing FDI accounts for the lion's share of inward FDI in LDCs. In 1988, the share of manufacturing FDI in total FDI in LDCs was approximately 66\%. In 1998, the share of manufacturing FDI in LDCs was approximately $50 \%$. As our results show that the positive impact of FDI on economic growth comes from manufacturing FDI rather than nonmanufacturing FDI, the host country could benefit more from inward FDI if policymakers appropriately reallocate the resources to attract FDI in specific sectors.

This article proceeds as follows: in Section II, we introduce the analytical framework as to how FDI can impact economic growth, followed by the empirical specification. In Section III, we present the data. Section IV discusses the empirical results. Section V concludes.

\section{Analytical Framework}

The model in this article is based on the idea of endogenous growth as in Romer (1990) and follows closely Borensztein et al. (1998). ${ }^{1}$

Suppose the economy produces a single consumption good $\left(Y_{t}\right)$ according to the production technology:

$$
Y_{t}=A H^{\alpha} \sum_{j=1}^{N} k(j)_{t}^{1-\alpha}
$$

where $A$ represents the state of environment in the economy; $H$ represents human capital and is assumed to be a given endowment. We assume that there are $N$ varieties of physical capital in the economy and $k(j)$ represents capital variety $j$.

Each variety of capital is produced by a specialized firm and the firm rents the capital good to consumption good producers at a rental rate $x(j)$. It follows that the demand for capital good $\mathrm{j}$ from the consumption good producers satisfies the following condition:

\section{Wang 3}




$$
x(j)_{t}=A H^{\alpha}(1-\alpha) k(j)_{t}^{1-\alpha}
$$

Two types of firms, domestic and foreign, produce different varieties of capital goods. Domestic firms produce $\mathrm{n}$ varieties of capital goods and foreign firms produce $n^{*}$ varieties. In other words, $N=n+n^{*}$.To increase the varieties of capital goods, firms must adopt advanced technology and the adoption of new technology requires a fixed set-up cost $(F)$. New advanced knowledge is brought into the country by foreign firms. The new knowledge brought into the host country by a foreign firm might already exist in other countries. Since imitating the technology used by a foreign firm and produce a new $k(j)$ is much easier than breaking through the technology frontier, it is assumed that the set-up cost $(F)$ is decreasing in the ratio of foreign firms to the total firms in the host country $\left(n^{*} / N\right)$. In addition, domestic firms imitate easier technology first. As more varieties of capital goods are produced, it gets harder to imitate more advanced foreign technology and produce a new variety. So the setup cost is assumed to be positively related to the ratio of the number of capital varieties produced in the host country to those produced in advance economies $\left(N / N^{*}\right)$ :

$$
F=F\left(\frac{n^{*}}{N}, \frac{N}{N}\right), \quad \text { where } \frac{\partial F}{\partial\left(n^{*} / N\right)}<0 ; \frac{\partial F}{\partial\left(N^{*} / N\right)}>0
$$

The production of capital $j$ has a constant marginal cost of one and the capital depreciates fully each period. As the fixed cost is incurred only in the beginning stage of production $(t=0)$, the subsequent profits for the firm producing a new variety of capital good in each period is:

$$
\pi(j)_{t}=x(j)_{t} k(j)_{t}-k(j)_{t}, \quad \forall t>0 .
$$

In equilibrium, $\pi(j)_{t}, x(j)_{t}$ and $k(j)_{t}$ will be constant overtime. Maximizing Equation 4 subject to the demand function given by Equation 2 presents the equilibrium level of production of capital $j:$

$$
k(j)=A^{1 / \alpha} H(1-\alpha)^{2 / \alpha}
$$

Equations 2 and 5 together generate the equilibrium rental rate for capital $j$ :

$$
x(j)=(1-\alpha)^{-1} .
$$

After solving the optimal profit in each period, one can calculate the present value of the total profit for a capital good producer: 


$$
\Pi(j)=-F\left(\frac{n^{*}}{N}, \frac{N}{N^{*}}\right)+\sum_{s=t}^{\infty}[x(j) k(j)-k(j)]\left(\frac{1}{1+r}\right)^{s+1-t}
$$

where $r$ represents the interest rate in the economy. Assume there is free entry in the capital goods market. The present value of profits should be zero for capital good producers. Solving for the zero profit condition and considering Equations 5 and 6, it follows that:

$$
r=A^{\frac{1}{\alpha}} \alpha(1-\alpha)^{\frac{2-\alpha}{\alpha}} F\left(\frac{n^{*}}{N}, \frac{N}{N^{*}}\right)^{-1} H .
$$

Suppose the representative household in the model maximizes utility over an infinite horizon:

$$
U=\sum_{t=0}^{\infty} \beta^{t} \log C_{t}
$$

where $C_{t}$ is the consumption of the final product $Y_{t}$. Given the interest rate $r$, the optimal consumption path is shown by the condition:

$$
\mathrm{g}_{c}=\beta(1+r)-1
$$

where $\mathrm{g}_{c}$ is the growth rate of consumption. In a steady state, the consumption growth rate $\mathrm{g}_{c}$ should be equal to the output growth rate $\mathrm{g}$ :

$$
\mathrm{g}_{c}=\mathrm{g}=\beta\left[\varsigma F\left(\frac{n^{*}}{N}, \frac{N}{N^{*}}\right)^{-1} H+1\right]-1
$$

where $\varsigma=A^{\frac{1}{\alpha}} \alpha(1-\alpha)^{(2-\alpha) / \alpha}$.

To explore empirically the effects of inward total FDI (FDI) on host country $i$ 's economic growth (g) at time $t$, we utilize the following formulation:

$$
\mathrm{g}_{i t}=\alpha+\underset{(+)}{\rho} F D I_{i t}+\underset{(-)}{\delta} \log Y_{i 0}+\phi H_{i 0}+\underset{(+)}{\lambda} A_{i t}+\varepsilon_{i t}
$$

where $Y_{0}$ stands for the initial GDP of the host country, which is a proxy for $\frac{N}{N^{*}} ; H_{0}$ is the initial human capital level; the group of control variables $A=\{$ Domestic investment $(+)$; Labour force (+); Trend (?)\} (see also Balasubramanyam et al., 1996).

We distinguish FDI and domestic investment in the model to allow for the two types of investment to affect a country's economic growth differently, depending upon the efficiency, management, or technology. Expected signs of the coefficients are attached to corresponding variables. Domestic investment is expected to have a positive coefficient because of its

\section{Wang 5}


contribution to capital formation. FDI is considered to promote technology improvement. And we expect the coefficient on FDI to be positive.

We then divide total FDI into different sector-level FDI and the empirical specification takes the following form:

$$
\mathrm{g}_{i t}=\alpha+\sum_{k} \rho_{k} F D I_{i k t}+\underset{(-)}{\delta} \log Y_{i 0}+\phi H_{i 0}+\underset{(+)}{\lambda} A_{i t}+\varepsilon_{i t}
$$

where $F D I_{i k t}$ represents inward FDI in sector $k$, country $i$, during period $t$. Other independent variables have the same interpretation as in Equation 12. FDI ikt variables are our variables of interest. If the coefficients on those sector-level FDI $\left(\rho_{k}\right)$ are significantly different from each other, it indicates that inward FDI in different sectors have differential impacts on host country's economic growth.

\section{Data}

Sector/industry-level FDI data are essential to our study. Recent disaggregated FDI data by country can be obtained from different issues of World Investment Directory (WID) published by the United Nations. However, no single issue of WID discusses FDI information in details for all countries. Each particular issue of WID covers only the information for a certain group of countries. To be more specific, the issue of 1992 WID discusses FDI in developed countries (DCs). The issue of 1994 covers FDI in Latin America and the Caribbean. The issue of 1996 covers FDI in Africa and West Asia. The issue of 2000 discusses FDI in countries of Asia and the Pacific. The most recent issue available to the authors, the issue of 2003 , discusses FDI in Latin American countries again.

Since the effect of FDI on economic growth is more relevant in LDCs and to be consistent with previous literature (Borensztein et al., 1998; Liu et al., 2002; Blonigen and Wang, 2005), we concentrate on inward FDI data in LDCs. The ideal data set for our study would include sector/industry-level inward FDI in a large number of LDCs. However, the disaggregated FDI data for LDCs discussed in the issues of 1994, 1996 and 2003 are typically not adequate for the purpose of our empirical study. For example, in the 1994 issue, countries in Latin America and the Caribbean generally have only two years of disaggregated FDI data available (1980 and 1990). Countries in Africa and West Asia do not report the sectorial distribution of FDI inflows at all.

Among all the issues available to the authors, the issue of 2000 provides the most consistent and complete disaggregated FDI data for certain countries. According to the 
availability of the disaggregated FDI data, our empirical sample includes 12 Asian economies: Bangladesh, Mainland China, Hong Kong, India, Indonesia, Korea, Malaysia, Pakistan, Philippines, Singapore, Thailand and Taiwan. The data set is unbalanced and spans up to 11 years from 1987 to 1997 when possible. The number of countries and time span of the sample is determined solely by data availability. Table 1 gives the descriptive statistics of FDI inflows in each of the 12 economies.

In our sample, FDI is measured as FDI inflows as a share of host countries' GDP.

The dependent variable is growth rate of per capita real GDP, measured as the log difference of per capita real GDP in host countries. GDP and per capita GDP come from the World Economic Outlook 2001 database provided by International Monetary Fund (IMF). Real values of GDP and per capita GDP are obtained using deflator from the World Development Indicators 1999 by World Bank. The average annual growth rate in our sample is $6.5 \%$, with a maximum of $11.2 \%$, a minimum of $-0.8 \%$ and a SD of $4 \%$.

Initial real GDP is measured as real GDP at the initial sample year for each host economy. When necessary, data reported in local currencies are converted into US dollars based on the current year average market exchange rate. The exchange rates are obtained from the Key Indicators of Developing Asian and Pacific countries (henceforth Key Indicators) 2001 published by the Asian Development Bank (ADB).

The initial level of human capital comes from Barro and Lee (1993) and is measured as the average years of secondary schooling in male population at the initial sample year for each host county/region. This is a commonly used measure of human capital in growth literature and FDI literature (Barro, 1997; Borensztein et al. 1998; Xu, 2000; Blonigen and Wang, 2005). Barro and Lee (1994) point out that this measure is most significantly correlated with economic growth. Data for education in Barro and Lee (1993) are reported every 5 years between 1960 and 1990 and the year of 1985 is picked as the initial year for countries/regions in our sample. We also use the measure of average years of secondary schooling in total population (SYR) and the average years of schooling in total population (TYR) from Barro and Lee (2001) as alternative measures of human capital. Different measures of human capital do not alter our empirical results. The results with SYR and TYR are not reported, but are available upon request.

Domestic investment is measured as the difference between gross fixed capital formation (GFCF) as a share of GDP and inward FDI as a share of GDP (i.e. (GFCF/GDP) - (FDI/GDP)). GFCF could be considered as the total investment in a country. Inward FDI is investment by foreign firms. As a result, the difference between GFCF and FDI as a share of GDP becomes a measure of domestic investment (United Nations, 1999; Agrawal, 2000). GFCF is obtained from 
Key Indicators 2001 by ADB.

The labour force growth is the growth rate of labour force, measured as the log difference of labour force. Labour force information is from the World Development Indicators by World Bank and the Key Indicators 2001 by ADB.

\section{Empirical Results}

\section{Total FDI}

Table 2 summarizes the regression results concerning the impact of total FDI inflows on economic growth. ${ }^{2}$ We estimate the regression using random effects estimation, weighted least squares (WLS) controlling for heteroskedasticity and feasible generalized least squares (FGLS) panel regression. Hausman test shows that the random effects estimation is preferred to fixed effects estimation in this case. WLS is applied because the volume and nature of inward FDI in small and large economies are quite different (Blonigen and Haynes, 2002). Real GDP of each economy is used as the weight. FGLS allows for a more general variance covariance matrix. FGLS and WLS give similar estimated coefficients. To save space, only results of random effects estimation and WLS are reported. ${ }^{3}$

As we can see, total FDI inflows have a positive and significant effect on host country's economic growth. Based on Random Effects estimation, we see that a 1\% increase in the FDI share of GDP is associated with a $0.78-1.17 \%$ increase in real per capita GDP growth. Similarly, WLS estimation shows that a $1 \%$ increase in FDI corresponds to a $0.87-1.23 \%$ increase in real per capita GDP growth, holding other things constant. ${ }^{4}$

Domestic investment is also an important source of economic growth. The coefficient on domestic investment has the expected positive sign and is significant. The initial level of human capital is positive and significant in all regressions, which indicates that the host country must be able to absorb the advanced technology embodied in FDI. The initial level of GDP has a significant and negative sign supporting the conditional convergence of economic growth widely suggested in the literature.

Another interesting finding from the results is that FDI is more efficient than domestic

investment in terms of promoting economic growth. Based on the estimation, using the full set of independent variables, the coefficient on FDI is 1.17 (Random Effects), while the coefficient on domestic investment is 0.44 . Wald tests show the coefficient on FDI is significantly greater than the coefficient on domestic investment at the $1 \%$ level. 


\section{Decomposition of Total FDI}

When using total FDI inflows data to estimate the growth effect of FDI, it is actually assumed that different sector-level FDI has homogeneous impact on host country's economic growth. However, there is no a priori reason for this assumption. Appropriate treatment is necessary to reveal the true impact of FDI on economic growth. Panel (A) and (B) in Table 3 summarize the regression results using disaggregated FDI for potential different effects of different sector-level FDI.

We first divide total inward FDI into manufacturing FDI (manufacturing) and nonmanufacturing FDI (nonmanufacturing). Manufacturing FDI includes FDI in Food, Beverage and Tobacco, Textiles, Leather and Clothing, Chemicals and Rubber products, Nonmetallic Products and Basic Metal Products, Machinery and Equipment, Electrical Machinery and Apparatus, Motor Vehicles and Other Transportation Equipment and Other Manufacturing. Nonmanufacturing sector includes Agriculture and Mining, Construction, Finance, Other Service and Others. Our sample annual average of manufacturing FDI as a share of GDP is $1.49 \%$. Over the sample period, FDI inflows in Bangladesh, Hong Kong, Malaysia and Singapore are exclusively in the manufacturing sector. FDI inflows in the manufacturing sector in the other eight economies fluctuate over the sample years. On average, manufacturing FDI accounts for 50-80\% of total FDI inflows in these economies with an exception of Pakistan. The annual average ratio of manufacturing FDI to total FDI inflows in Pakistan is 16\%. The majority of Pakistan's inward FDI is in Agriculture and oil-related industries. According to the Board of Investment (BOI), Government of Pakistan, the number one reason for foreign investors to invest in Pakistan is the 'abundant land and natural resources'. ${ }^{5}$ In our sample, the annual average ratio of Agricultural FDI and Other FDI to the total FDI inflows in Pakistan is 56\%.

Panel (A) in Table 3 represents results for the two-sector decomposition. As we can see, FDI in the manufacturing sector has a positive and significant impact on economic growth, but nonmanufacturing FDI does not contribute much to the host country's economic growth. Based on Random Effects estimation, we find that a 1\% increase in manufacturing FDI as a share of GDP leads to a $1.55 \%$ increase in per capita real GDP growth, ceteris paribus. Furthermore, the Random Effects estimation in Table 2, which evaluates the contribution of total FDI to economic growth, shows that a 1\% increase in FDI as a share of GDP corresponds to a $1.17 \%$ increase in economic growth, holding other things constant. It appears that manufacturing FDI has a much stronger positive effect on a country's economic growth than one has generally expected.

One concern with the empirical results is that the significance of manufacturing FDI might be driven by the fact that FDI inflows are exclusively in the manufacturing sector in four of our

\section{Wang 9}


economies mentioned above. To address this issue, we estimate those regressions by excluding Bangladesh, Hong Kong, Malaysia and Singapore. The results do not change substantially compared to those from the share of GDP is $1.49 \%$.

Panel (B) in Table 3 presents a more detailed FDI decomposition results. In panel (B), total FDI inflows are divided into six sectors, with each expressed as a share of the host economy's GDP: Agriculture and Mining (agriculture), Manufacturing (manufacturing), Construction (construction), Finance (finance), Other Service (service) and Others (others). After the decomposition of FDI, the coefficient on manufacturing FDI is positive and significant in all regressions. Coefficients on most other sector-level FDI are not significant at conventional levels. The results indicate that only FDI in the manufacturing sector plays an important role in enhancing economic growth of the host economies in our sample. Our sample average of manufacturing FDI as a share of GDP is $1.49 \%$. The point estimate of 1.74 implies that without manufacturing FDI, the sample average economic growth would drop by $2.59 \%$, holding other things constant. ${ }^{7}$ The actual effect will be smaller since we do not consider here the substitutability between domestic investment and FDI in the form of cross-border merger and acquisition.

Results from Panel (B) in Table 3 also show that the magnitude of the coefficient on manufacturing FDI (1.74-2.32) is larger than the magnitude of the coefficient on total FDI inflows (1.17-1.23) in Table 2. It suggests that previous studies have underestimated the effect of manufacturing FDI on host countries' economic growth because of aggregation. Indeed, the difference is not negligible. The estimated growth effect of manufacturing FDI could be $48 \%$ larger than the estimated growth effect of total FDI. ${ }^{8}$ As we have noticed, for most LDCs, the lion's share of FDI inflows goes to manufacturing sector. And for some LDCs, FDI inflows are solely in manufacturing sector. Results from the disaggregated FDI estimation might provide better guidance for LDCs' policies toward FDI, or policies toward FDI in different sectors or industries.

Most of the FDI inflows in these 12 Asian economies come from Japan, the US and Western Europe. One possible reason why the growth-promoting effect is stronger in the manufacturing sector in the sample is that spillover effects of FDI might be stronger in manufacturing sector. The manufacturing sector includes both labour-intensive industries (food and beverage; textiles, leather and clothing) and R\&D-intensive industries (computers, electrical machinery) but other sectors do not. ${ }^{9}$

In labour-intensive industries, a large number of host country workers are employed by foreign firms. The spillover effects may be important in the short run through the training of host 
country workers. Furthermore, due to 'cost differentials in research salaries between developing and industrialized countries' (United Nations, 1999), there is also R\&D-intensive FDI in manufacturing sector. ${ }^{10} \mathrm{~A}$ high concentration of R\&D by the foreign affiliates may help to improve the skill or technology level of host country firms and promote growth. For example, the 1994 R\&D expenditure of the US affiliates in Singapore, Taiwan, Hong Kong and Malaysia accounted for about $54 \%$ of US affiliates R\&D in developing countries.

Another possible reason for the different effects of manufacturing FDI and other sector-level FDI, such as service, might be caused by the form of FDI entry, i.e. greenfield investment and M\&A, in different sectors. It would be interesting to further investigate this issue. Reliable estimation requires sector-level/ industry-level greenfield and M\&A in host countries. However, due to data availability, this detailed study is beyond the scope of our current article. Instead, we look at country-level greenfield and M\&A and their effects on economic growth. M\&A data come from United Nations Conference on Trade and Development (UNCTAD) foreign direct investment database. There are no available data on greenfield investment. Our best estimate of greenfield investment is to take the difference between total FDI and M\&A. The sample size is reduced to 88 for the greenfield and $M \& A$ estimation. We find that greenfield investment tends to have a positive and significant impact on economic growth, while the coefficient on $M \& A$ generally is not significant at conventional levels. Intuitively, greenfield investment is associated with addition of production capacity, while M\&A is typically associated with simple transfer of ownership.

Furthermore, we separate our sample into different sub-samples according to host countries' greenfield FDI and M\&A information. First, we collect observations satisfying gfdummy $=1$ (gfdummy is a dummy variable, which takes the value of 1 if a country's greenfield investment share as a GDP is greater than the sample annual average greenfield investment share as a GDP; 0 otherwise). Regression based on these observations will help us to detect whether and how the coefficients on sector-level FDI will change if the country has a larger share of greenfield investment than other countries in the sample. If forms of FDI in different sectors affect economic growth, we should observe some changes in the estimated coefficients. In addition, we collect observations satisfying $g f$ madummy $=1$ ( $g f_{-}$madummy is a dummy variable, which takes the value of 1 if a country's greenfield investment share of GDP is greater than its M\&A share of GDP; 0 otherwise). This regression helps us to detect whether and how the coefficients on sector-level FDI will change if the country has predominantly greenfield investment. Again, if forms of FDI in different sectors affect the growth impacts of FDI, we might be able to observe some changes in the estimated coefficients.

\section{Wang 11}


Empirical results from the two sub-sample regressions do not differ qualitatively from the whole sample regression. Manufacturing FDI has positive and significant coefficient, while coefficients on other sector-level FDI are not significant at conventional levels. These preliminary results certainly do not suggest forms of FDI in different sectors play insignificant role in affecting economic growth. Rather, they provide some guidance for our future research regarding this topic. Indeed, more detailed break-down of FDI data in host countries is required to provide a better answer. ${ }^{11}$

\section{Decomposition of Sector FDI}

We further decompose inward FDI in the manufacturing sector into several industries: Food, Beverage and Tobacco (FBT), Textiles, Leather and Clothing ( $T$ ), Chemicals and Rubber Products (CR), Nonmetallic Products and Basic Metal Products (MET), Machinery and Equipment, Electrical Machinery and Apparatus (MAC), Motor Vehicles and Other Transportation Equipment (MOTOR), Wood $(W)$ and Other Manufacturing $(O)$. All the industrial level FDI inflows are expressed as a share of GDP of host countries/regions.

Our sample in this case consists of only ten economies instead of the original 12 economies. There is virtually no industry-level information on FDI inflows in the manufacturing sector for China and Pakistan. Therefore, these two countries are excluded from the regression. Based on our sample, the annual average share of $T$ FDI in total manufacturing FDI is 0.06 . In other words, each year, 6\% of manufacturing FDI flows into Textiles, Leather and Clothing industries. FDI in MOTOR accounts for $5 \%$ of total FDI in manufacturing sector. FDI in FBT and MET account for 7 and 10\% of total manufacturing FDI, respectively. Around $28 \%$ of manufacturing FDI flows into MAC, $22 \%$ to $\mathrm{CR}, 3 \%$ to $\mathrm{W}$ and $18 \%$ to O. Table 4 reports the regression results. Based on different regressions, coefficients on FDI variables in nonmanufacturing sectors are not significant at conventional levels. The most robust result is that the Other Manufacturing FDI has a significant and positive coefficient. FDI in MOTOR, $T$ and MAC seem to also help economic growth. However, these results are less robust.

\section{Endogeneity}

One may also be concerned with that inward FDI might be endogenous. FDI inflows can promote host countries' economic growth. However, a country with a high growth rate could possibly attract more FDI because of a better investment environment. We therefore, adopt the instrumental variables (IV) method to control for the potential endogeneity problem. Theoretically speaking, ideal instruments should be variables correlated with FDI, but not with the error term.

\section{Wang 12}


In reality, good instruments are often hard to obtain. We collect the lagged FDI, openness, business environment risk index, and log value of host country's area as instruments in this study. Openness is measured as the sum of imports and exports divided by host country's GDP. The business environment risk index is obtained from Business Environment Risk Intelligence S.A. The index ranges from 0 to 100 and is a composite score of operation risk index, political risk index and remittance and repatriation factor. A score of 100 indicates a perfect environment for foreign business. A score between 0 and 39 represents an unacceptable environment for foreign business operation. Including area as one of the instruments is to catch the effect that some inward FDI is oriented toward the host country's domestic market. A large area could suggest a

relatively large domestic market. Data on area come from Frankel and Romer (1999). ${ }^{12}$

Table 5 reports the IV estimation results. The first column summarizes the economic impact of total FDI inflows. The second column shows the impact of manufacturing FDI and the impact of nonmanufacturing FDI.

Consistent with our previous findings in this article, manufacturing FDI has a significant and positive coefficient. Nonmanufacturing FDI has a negative coefficient, while not statistically significant. The results confirm that manufacturing FDI contributes positively to economic growth but non-manufacturing FDI does not. Also, aggregating different types of FDI inflows understates the actual effect of manufacturing FDI on host country's economic growth.

\section{Conclusion}

The impact of FDI on growth is intriguing and of intense interest for policy-making purposes. Even though endogenous growth theory predicts a positive relationship between inward FDI and economic growth, the empirical studies typically generate ambiguous results. We suggest that using total FDI in previous studies might blur the effects of FDI and lead to such ambiguous results. This article's contribution is to distinguish the impacts of inward FDI on economic growth by using FDI in different sectors. It allows us to test whether different sector-level FDI inflows have different effects on a host country's economic growth. Panel regressions based on a sample of 12 Asian economies over the period of 1987 to 1997 show that different types of FDI do have different impacts on host country's economic growth. Inward FDI in the manufacturing sector plays a very important role in enhancing the economic growth, but FDI in nonmanufacturing sectors does not. Furthermore, since manufacturing FDI accounts for the lion's share of FDI inflows in developing countries, logically it makes sense to detect the effect of different sector-level inward FDI, manufacturing FDI in particular. If FDI inflows in the manufacturing sector have a stronger impact on economic growth, then favourable policies can 
be made to attract more FDI in that sector. Interestingly, we also find that using the total FDI inflows underestimates the actual effect of manufacturing FDI on host country's economic growth by at least $48 \%$. In other words, the effect of manufacturing $\mathrm{FOI}$ in our article is stronger than the effect of total FDI shown in previous studies.

Our results provide some support for the potential different effects of sector-level FDI in Terms of enhancing growth. There are other interesting issues that deserve further exploration. For instance, are different growth effects of sector-level FDI caused by different forms of FDI? Another possible extension of this article is to study the growth in different sectors. To be more specific, nonmanufacturing FDI in the agricultural and the mining sector might not have a significant impact on the overall per capita GDP growth, but it might promote growth in agricultural and mining sectors. Moreover, if data over longer time periods are available, time-varying estimation, such as rolling regressions, could be used to trace the impact of FDI corresponding to changes in international trade policies in host countries over years.

\section{Notes}

1. Endogenous growth theory (Romer, 1986; Romer, 1990; Aghion and Howitt, 1992) stresses that endogenous technology improvement or innovation is the engine of sustained economic growth. For example, Romer (1990) takes an approach that incorporates industrial innovation as the source of economic growth. He suggests that research and development (R\&D) are necessary to obtain new ideas for increasing the variety or quality of intermediate goods, which in turn help to increase the quantity or quality of final output. Although technology improvement is the link between FDI and economic growth, it's not the focus of this article.

2. Portmanteau and Bartlett's white noise tests are conducted on each country's WLS regression residuals. Both tests fail to reject the null hypothesis of white noise at conventional levels for total FDI inflows regression and FDI decomposition regressions.

3. Results based on other estimation methods can be obtained upon requests.

4. In an earlier version of this article, gross domestic savings are used as a proxy for domestic investment. The correlation between gross domestic savings and our current measure of domestic investment is 0.7613 . We assume that domestic firms are most likely to borrow from domestic financial institutions and finance their investment. As a result, domestic savings can be a proxy for investment made by domestic firms. The two sets of results do not differ qualitatively. The coefficient on FDI tends to be smaller when we use gross domestic savings as a proxy for domestic investment.

\section{Wang 14}


5. Quote from BOI, Government of Pakistan.

http://www.pakboi.gov.pk/FAQs/why_invest_in_pakistan.html

6. The dependent variable is growth of real per capita GDP, and FDI variable is measured as a share of GDP. It is likely that the correlation between FDI and economic growth is because that both measures have GDP in them. Regression analysis using real FDI in billions of dollars shows that the manufacturing FDI effect is positive and significant at the $1 \%$ level and nonmanufacturing FDI effect is negative and significant. To be consistent with the measure adopted in previous literature, in this paper we keep the measure of FDI as a share of host country's GDP.

7. The sample average of manufacturing FDI as a share of GDP is $1.49 \%$. Based on random effects estimation, the growth impact of manufacturing FDI is $1.49 * 1.74=2.59 \%$, ceteris paribus.

8. $(1.74-1.17) / 1.17=0.487$.

9. The literature of the spillover effect of FDI provides a link between investment and economic growth. This article does not focus on detailed spillover effect of FDI. See Caves (1974), Germidis (1977), Globerman (1979), Mansfield and Romeo (1980), Barrell and Pain (1997), and Aitken and Harrison (1999) for further discussion about this topic.

10. For example, Sony Corporation of Japan has nine R\&D units in developing Asian countries. Three of them are in Singapore, three in Malaysia, one in Korea, one in Taiwan, and one in Indonesia. They conduct R\&D on different Sony electronic products, such as the optical data storage devices, the design of compact discs, and so on. Over time, this R\&D 'generally shades into genuine innovation, especially where the skill base is good ...' (United Nations, 1999).

11. The regressions are not reported, but are available upon request.

12. The risk index is not available for Bangladesh and Hong Kong. Thus, instruments of FDI for Hong Kong and Bangladesh do not include the risk index.

\section{References}

Aghion, P. and Howitt, P. (1992) A model of growth through creative destruction, Econometrica, 60, 323-51.

Agrawal, P. (2000) Economic impact of foreign direct investment in South Asia, Working Paper. World Bank.

Aitken, B. J. and Harrison, A. (1999) Do domestic firms benefit from direct foreign investment? Evidence from Venezuela, American Economic Review, 89, 605-18. 
Alfaro, L., Chanda, A., Kalemli-Ozcan, S. and Sayek, S. (2004) FDI and economic growth: the role of local financial markets, Journal of International Economics, 64, 89-112.

Balasubramanyam, V. N., Salisu, M. and Sapsford, D. (1996) Foreign direct investment and growth in EP and IS countries, The Economic Journal, 106, 92-105.

Barrell, R. and Pain, N. (1997) Foreign direct investment, technological change, and economic growth within Europe, The Economic Journal, 107, 1770-86.

Barro, R. J. (1997) Determinants of Economic Growth: A Cross-Country Empirical Study, MIT Press, Cambridge and London.

Barro, R. J. and Lee, J. W. (1993) International comparisons of educational attainment, Journal of Monetary Economics, 32, 363-94.

Barro, R. J. and Lee, J. W. (1994) Sources of economic growth, Carnegie Rochester Conference Series on Public Policy, 40, 1-46.

Barro, R. J. and Lee, J. W. (2001) International data on educational attainment: updates and implications, Oxford Economic Papers, 53, 541-63.

Blomstrom, M., Lipsey, R. and Zejan, M. (1994) What explains growth in developing countries? in Convergence of Productivity: Cross-National Studies and Historical Evidence (Eds) W. Baumol, R. Nelson and E. Wolff, Oxford University Press, Oxford and New York, pp. 243-59.

Blonigen, B. and Haynes, S. (2002) Antidumping investigations and the pass-through of antidumping duties and exchange rates, American Economic Review, 92, 1044-61.

Blonigen, B. and Wang, M. (2005) Inappropriate pooling of wealthy and poor countries in empirical FDI studies, in Does Foreign Direct Investment Promote Development? (Eds) T. Moran, E. Graham and M. Blomstrom, Institute for International Economics Publication, Washington, DC, pp. 221-44.

Borensztein, E., De Gregorio, J. and Lee, J. W. (1998) How does foreign direct investment affect economic growth? Journal of International Economics, 45, 115-35.

Carkovic, M. and Levine, R. (2005) Does foreign direct investment accelerate economic growth? in Does Foreign Direct Investment Promote Development? (Eds) T. Moran, E. Graham and M. Blomstrom, Washington, DC, pp. 195-220.

Caves, R. (1974) Multinational firms, competitions, and productivity in host-country market, Economica, 41, 176-93.

Chakraborty, C. and Basu, P. (2002) Foreign direct investment and growth in India: a cointegration approach, Applied Economics, 34, 1061-73.

Choe, J. I. (2003) Do foreign direct investment and gross domestic investment promote 
economic growth? Review of Development Economics, 7, 44-57.

Choi, C. (2004) Foreign direct investment and income convergence, Applied Economics, 36, 1045-49.

Chuang, Y.-C. and Hsu, P.-F. (2004) FDI, trade and spillover efficiency: evidence from China's manufacturing sector, Applied Economics, 36, 1103-15.

Chuang, Y. C. and Lin, C. M. (1999) Foreign direct investment, R\&D and spillover efficiency: evidence from Taiwan's manufacturing firms, Journal of Development Studies, 35, 11737.

De Mello, L. R. (1997) Foreign direct investment in developing countries and growth: a selective survey, Journal of Development Studies, 34, 1-34.

Frankel, J. A. and Romer, D. (1999) Does trade cause growth? American Economic Review, 89, 379-99.

Germidis, D. (1977) Transfer of Technology by Multinational Corporations, Development Center of the Organization for Economic Cooperation and Development, Paris.

Globerman, S. (1979) Foreign direct investment and 'spillover' efficiency benefits in Canadian manufacturing industries, Canadian Journal of Economics, 12, 42-56.

Kottaridi, C. (2005) The 'core-periphery' pattern of FDI-led growth and production structure in the EU, Applied Economics, 37, 99-113.

Liu, X., Burridge, P. and Sinclair, P. J. N. (2002) Relationships between economic growth, foreign direct investment and trade: evidence from China, Applied Economics, 34, 143340.

Mansfield, E. and Romeo, A. (1980) Technology transfer to oversea subsidiaries by U.S.-based firms, Quarterly Journal of Economics, 95, 737-50.

Mencinger, J. (2003) Does foreign direct investment always enhance economic growth? Kyklos, 56, 493-510.

Nair-Reichert, U. and Weinhold, D. (2001) Causality tests for cross-country panels: a new look at FDI and economic growth in developing countries, Oxford Bulletin of Economics and Statistics, 63, 153-71.

Perkins, D. H., Radelet, S., Snodgrass, D. R., Gillis, M. and Roemer, M. (2001) Economics of Development, W. W. Norton \& Company, Inc, New York.

Romer, P. (1986) Increasing returns and long-run growth, Journal of Political Economy, 94, 1002-37.

Romer, P. (1990) Endogenous technological change, Journal of Political Economy, 98, S71102. 
UNECE (2001) Survey of Europe 2001: Ch. 5: Economic Growth and Foreign Direct Investment in the Transition Economies, Luxembourg.

United Nations (1999) World Investment Report 1999, United Nations, New York.

Xu, B. (2000) Multinational enterprises, technology diffusion, and host country productivity growth, Journal of Development Economics, 62, 477-93.

Yao, S. (2006) On economic growth, FDI and exports in China, Applied Economics, 38, 339-51. 


\section{Appendix}

\section{Table 1: Descriptive Statistics FDI Inflows in Each Economy (Million \$)}

\begin{tabular}{lccccc}
\hline & Mean & Median & Maximum & Minimum & SD \\
\hline Bangladesh & 411.7006 & 99.64481 & 1498.157 & 26.1104 & 513.9704 \\
China & 4554.54 & 51004 & 111435.8 & 3709 & 40471.1 \\
HK & 225.3007 & 227.6873 & 475.1985 & -59.7561 & 149.4854 \\
India & 329.6496 & 230.2857 & 794.9429 & 142.7469 & 240.6809 \\
Indonesia & 17242.06 & 9550.6 & 39944.7 & 4713.5 & 13147.17 \\
Korea & 1441.267 & 1282.8 & 3202.8 & 802.5 & 740.2405 \\
Malaysia & 4276.964 & 3992.671 & 6965.921 & 817.4603 & 2234.35 \\
Pakistan & 387.239 & 360.637 & 789.4083 & 110.0404 & 224.325 \\
Philippines & 465.82 & 352.9 & 1281 & 64 & 393.4426 \\
Singapore & 1506.279 & 1573.048 & 2205.634 & 810.4265 & 426.5629 \\
Taiwan & 2096.236 & 1778.4 & 4266.6 & 1182.6 & 920.3397 \\
\hline
\end{tabular}




\section{Table 2: Regression Results for Impact of FDI on Economic Growth}

\begin{tabular}{|c|c|c|c|c|c|c|c|c|}
\hline \multirow{2}{*}{$\frac{\text { Variable }}{F D I}$} & \multicolumn{2}{|c|}{ Random effects } & \multicolumn{2}{|c|}{ WLS } & \multicolumn{2}{|c|}{ Random effects } & \multicolumn{2}{|c|}{ WLS } \\
\hline & $0.7851 * *$ & $(0.1981)$ & $0.8793^{* * *} *$ & $(0.2234)$ & $1.1786^{* * *}$ & $(0.2032)$ & $1.2334 * * *$ & $(0.2235)$ \\
\hline Domestic investment & $0.1999 * *$ & $(0.0926)$ & 0.2788 & $(0.2464)$ & $0.4466 * * *$ & $(0.1022)$ & $0.5084 * *$ & $(0.2193)$ \\
\hline$H_{0}$ & $0.0320 * * *$ & $(0.0077)$ & $0.0330 * * *$ & $(0.0064)$ & $0.0360 * * *$ & $(0.0073)$ & $0.0349 * * *$ & $(0.0033)$ \\
\hline Labour force & 0.0218 & $(0.3056)$ & $0.3695^{*}$ & $(0.1819)$ & 0.0357 & $(0.2809)$ & 0.1963 & $(0.1731)$ \\
\hline$Y_{0}$ & $-0.0259^{*}$ & $(0.0109)$ & $-0.0351^{*}$ & $(0.0192)$ & $-0.0495^{* * *}$ & $(0.0115)$ & $-0.0537 * * *$ & $(0.0156)$ \\
\hline Trend & & & & & $-0.0106^{* * *}$ & $(0.0022)$ & $-0.0095 * * *$ & $(0.0029)$ \\
\hline \# Of observations & 121 & & 121 & & 121 & & 121 & \\
\hline Adjusted- $R^{2}$ & 0.1503 & & 0.1577 & & 0.2847 & & 0.2235 & \\
\hline
\end{tabular}

Note: * ${ }^{* *}$ and ${ }^{* * *}$ denotes significance at 0.10, 0.05 and 0.01 level, respectively.

Numbers in parentheses are standard errors of the estimated coefficients. 
Table 3: Regression Results for FDI Decomposition and Economic Growth (Dependent Variable: Growth of Real per Capita GDP)

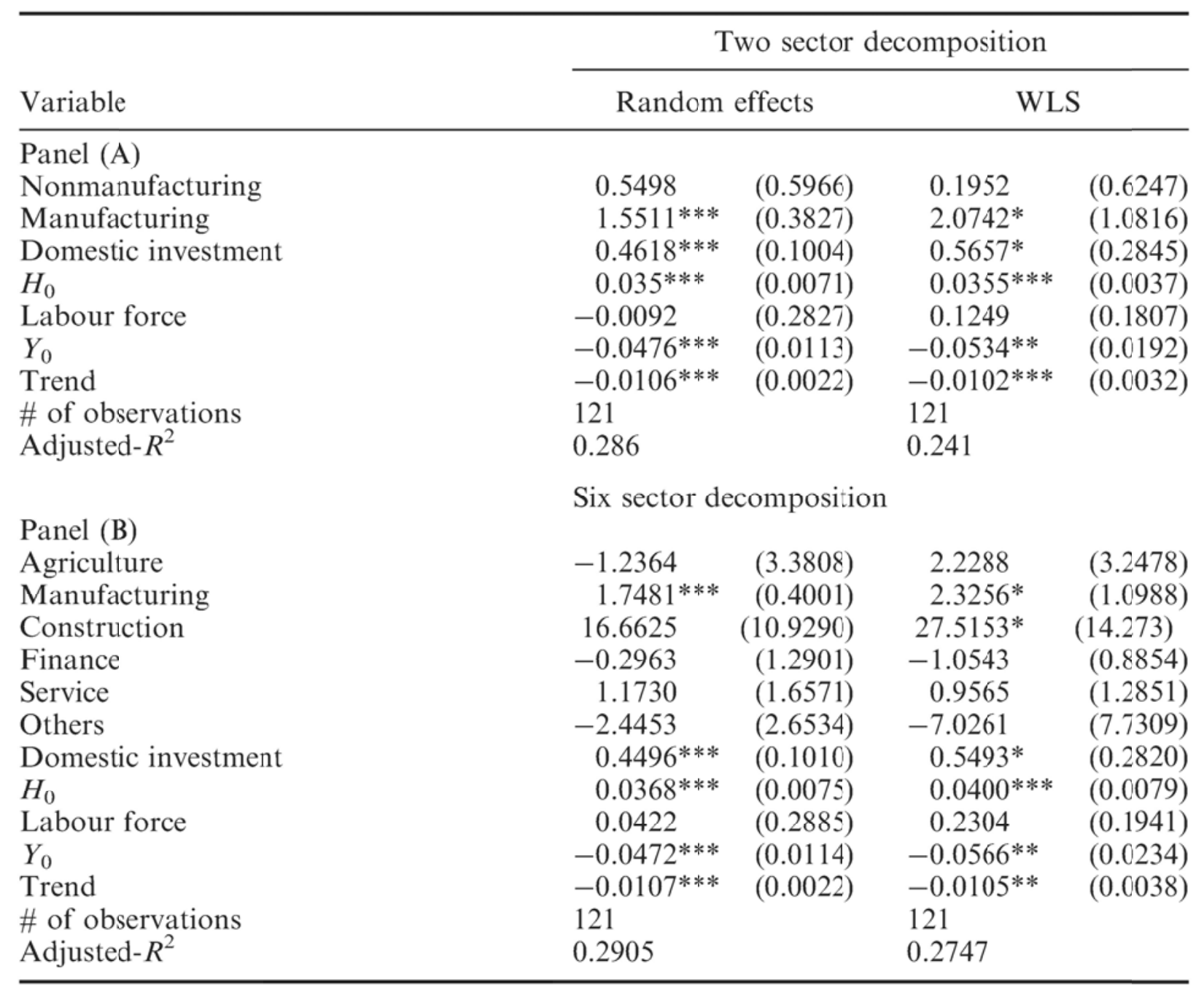

Notes: ${ }^{*},{ }^{* \star}$ and ${ }^{* \star *}$ denotes significance at $0.10,0.05$ and 0.01 level, respectively. Numbers in parentheses are standard errors of the estimated coefficients. 
Table 4: Results for Decomposition of Manufacturing FDI (Dependent Variable: Growth of Real per Capita GDP)

\begin{tabular}{lcrrr}
\hline Variable & \multicolumn{2}{c}{ Random effects } & \multicolumn{2}{c}{ WLS } \\
\hline Agriculture & -0.1387 & $(3.7079)$ & -1.5105 & $(2.9309)$ \\
Construction & 7.9383 & $(13.5575)$ & 8.1662 & $(9.3688)$ \\
Finance & 5.6912 & $(5.7870)$ & 11.7758 & $(9.6465)$ \\
Service & 0.5304 & $(1.9452)$ & 0.1466 & $(1.2658)$ \\
Others & 3.1768 & $(3.1411)$ & 0.7010 & $(3.1439)$ \\
FBT & 21.9041 & $(14.5256)$ & 16.5073 & $(17.1999)$ \\
T & $10.0286^{* *}$ & $(4.3594)$ & 7.4791 & $(4.3232)$ \\
W & -0.6037 & $(2.1120)$ & 0.0465 & $(1.4498)$ \\
CR & -0.8430 & $(1.1841)$ & -0.3645 & $(0.7727)$ \\
MET & -2.5425 & $(2.8033)$ & $-3.4555^{*}$ & $(1.8150)$ \\
MAC & 2.8329 & $(1.7712)$ & $3.9322^{*}$ & $(2.1002)$ \\
MOTOR & $35.7631^{*}$ & $(18.9665)$ & 22.0226 & $(26.1028)$ \\
O & $2.8209^{*}$ & $(1.5958)$ & $3.1388^{* * *}$ & $(0.4230)$ \\
$H_{0}$ & $0.0355^{* * *}$ & $(0.0072)$ & $0.0345^{* * *}$ & $(0.0053)$ \\
Domestic investment & $0.3238^{* *}$ & $(0.1274)$ & $0.1715^{* *}$ & $(0.2169)$ \\
Labour force & 0.2046 & $(0.3671)$ & 0.5188 & $(0.4333)$ \\
$Y_{0}$ & $-0.0284^{*}$ & $(0.0152)$ & -0.0171 & $(0.0198)$ \\
Trend & $-0.0111^{* * *}$ & $(0.0025)$ & $-0.0093 *$ & $(0.0043)$ \\
\# of observations & 99 & & 99 & \\
Adjusted- $R^{2}$ & 0.3053 & & 0.2539 & \\
\hline
\end{tabular}

Note: *, ${ }^{* *}$ and ${ }^{* \star *}$ denotes significance at $0.10,0.05$ and 0.01 level, respectively. Numbers in parentheses are standard errors of the estimated coefficients. 
Table 5: Results for IV Regressions

\begin{tabular}{|c|c|c|c|c|}
\hline \multirow[b]{2}{*}{ FDI } & \multicolumn{2}{|l|}{ IV } & \multicolumn{2}{|l|}{ IV } \\
\hline & $0.9988 * * *$ & $(0.2504)$ & & \\
\hline Nonmanufacturing & & & -0.8566 & $(0.8139)$ \\
\hline Manufacturing & & & $2.0866 * * *$ & $(0.4800)$ \\
\hline$H_{0}$ & $0.028 * * *$ & $(0.0082)$ & $0.0253 * * *$ & $(0.0082)$ \\
\hline Domestic investment & $0.3736^{* * *}$ & $(0.1043)$ & $0.3639 * * *$ & $(0.1015)$ \\
\hline Labour force & -0.0668 & $(0.3028)$ & -0.2144 & $(0.3001)$ \\
\hline$Y_{0}$ & $-0.0433 * * *$ & $(0.0124)$ & $-0.0349 * * *$ & $(0.0128)$ \\
\hline Trend & $-0.0077^{* *}$ & $(0.0026)$ & $-0.0073 * * *$ & $(0.0026)$ \\
\hline No of observations & 109 & & 109 & \\
\hline Adjusted- $R^{2}$ & 0.1668 & & 0.2115 & \\
\hline
\end{tabular}

Note: * ** and ${ }^{* * *}$ denotes significance at 0.10, 0.05 and 0.01 level, respectively.

Numbers in parentheses are standard errors of the estimated coefficients. 